\title{
離島振興法の成立背景と後進性からみた 振興事業の課題
}

\author{
久保田 恵都子 1 \\ 1正会員 中央大学大学院理工学研究科都市人間環境学専攻（干112-8551 東京都文京区春日1-13-27） \\ E-mail: a18.faee@g.chuo-u.ac.jp
}

\begin{abstract}
わが国の離島地域の振興は, 1953 (S28)年に成立した離島振興法に始まる. 本研究は, 今後の離島振興 政策の検討に資するために，立法措置の必要性と後進性というキーワードに着目し当時の離島の経済社会 状況について検討した。 その結果，法制定当時，国と離島関係都県の地域振興の方針にスタンスの違いが あり, 離島開発の優先順位はきわめて低かったこと, また半数以上が第一次産業従事者で, その一人当た りの所得は低く，資本力・行財政力が乏しかったこと等を明らかにし，離島振興事業の課題を考察した。
\end{abstract}

Key Words : Remote Islands Development Act, legislative background, removal of backwardness, regional development policy, remote islands issues

\section{1. はじめに}

我が国の離島地域の振興は，1953(S28)年に成立した離 島振興法(以下，離振法という)に始まる。それからの離 島では，道路・港湾事業等を中心とした八ード整備事業 が推進され，現在は地域活性化事業や定住促進の取組み にも支援している.

離振法成立の当初は, 離島の後進性の除去と民生の安 定を目的に成立している，当時は，戦後日本の復興，経 済的自立を目指寸中，国土を総合的に利用・開発・保全 することを目的に「国土総合開発法(以下，国総法とい う)」が1950(S25)年に制定される一方，「積雪寒冷単作 地帯振興臨時措置法」(1951(S26))や「特殊土袞地带災害 防除及び振興臨時措置法」(1952(S27))など農業生産に関 する特殊地域の立法も制定され始めた。 条件不利地域の 地域振興に関する法律は，離振法をはじめ山村法，半島 振興法，過疎法等があり，国土の均衡ある発展の観点か ら国が地域格差の是正を図るための支援策で, 離振法は 比較的早い時期に制定され，その先駆けとなった.

制定経緯は, 全国離島振興協議会・(財)日本離島セン ター発行の文献1,2,3) 亿詳述され, 当時の行政の動向や見 解を窥い知ることができる．既往研究では，鈴木 4 (5) 5) の, 7 は，前述の文献をもとに制定をリードした人物に焦点を あてて離振法の成立経緯, また法案の審議内容から地域 指定の瞹昧さを指摘している．小澤8は，離振法の目的 と手段の変遷を整理し, 離島地域のガバナンスと将来の
展望を示唆している.しかし, 国総法の特定地域総合開 発計画と離島開発の関係や, 離島を対象とした地域開発 事業に立法措置を必要とした当時の離島の状況(後進性) については明確に明らかにされていない。

現在，離振法の事業推進により徐々に本土と離島との 地域格差が解消されつつあり, 後進性の用語も消去され たが，当時より人口半減した現在でも若者の島外流出は 変わらない.また離島には領海及び排他的経済水域等の 保全等の重大な役割が付加され，2016(H28)年には新た に離島を対象とした有人国境離島法も制定された. 離島 をめぐるさまざまな環境が変化する今日，これまでの離 島振興のあり方を改めて評価し, 再設定を行う時期にあ ると考える. そのためには, 離島振興の起点や, なぜ既 存制度や事業の活用ではなく, 立法措置の必要があった のか，その要因や当時の離島の状況を明らかにした上で， 離島振興施策の事後評価を行う必要があると考える.

そこで本研究は, この第1段階として離振法成立時に おける関係機関の動向や背景等から国や離島関係都県の 地域振興の方針と離島の位置づけを明らかにする. あわ せて, 離振法成立の理由となった後進性に着目して, 当 時の離島の状況を整理し，その状況により展開された当 初の離島振興事業の方向性を明らかにすることを目的と する. 


\section{2. 研究方法}

離島地域の振興が，国の既存制度や事業の活用ではな く立法を必要とした理由を探るため, 当時の国と離島関 係都県における地域振興の方針に着目寸る．また，離振 法成立のポイントとなった“後進性”をキーワードに，当 時の離島の状況を把握する．なお，離島振興に関する法 律は離振法のほかに，奄美群島，小笠原諸島，沖縄に関 する特別措置法が存在する。 これらは各々本土復帰年又 は翌年に成立し，本研究対象当時は日本の施政権下では なかったことを付記しておく。

\section{(1) 関係機関の地域振興方針}

当時，国が制定したばかりの国総法に着目し，国の地 域開発における方向性を把握する，また，全国離島振興 協議会・(財)日本離島センター発行の文献と既往研究に より，各関係機関(国，各都県)や学界が，どのような状 況にあり離振法制定に動いたのかについて整理する.

\section{（2）後進性に着目した離島の状況}

離振法成立のポイントとなった後進性とは何かを探る ため,「後進性」をキーワードに文献調査し，また当時 の離島課題のひとつであった「人口過剩」と, 経済状況 を把握するために「産業構造とその所得」を切り口に, 当時の離島の状況を明らかにする.

\section{3. 関係機関の地域振興方針}

\section{(1) 国 ${ }^{13,2), 33,99,10), 11, ~ 12), ~ 13), ~ 14), ~ 15), ~ 16, ~ 17, ~ 18), ~ 19, ~ 20, ~ 21) ~}$}

離振法制定に動き出した1950(S25)年頃，国内人口は戦 後のベビーブームや海外からの復員軍人, 引揚者等によ って急増しており, 都市の戦災復興と食糧や原材料の確 保・自給化等が喫緊の課題であった，GHQ占領下にお ける戦後経済の再建と自立を図るためには, 資源主義に よるべきか，また貿易主義をとるべきかが大いに論ぜら れた. 佐藤 ${ }^{11}$ は, この時期の地域開発の課題は大別して 1)戦災復興，2)災害復興，3)食糧増産，4)産業復興にあり， これらが密接な関連をもって同時的に遂行寸る必要があ ったことを指摘している. そのような中, 戦後直後の傾 斜生産方式からの転換と台風被害による防災対策意識の 高まり，また米国のTVA方式をモデルとした河川総合開 発等による総合的な地域開発が注目された。 これら特定 地域の開発を保障する制度として「総合開発法」の制定 が検討されたが，最終的に「国土総合開発法」は4種の 総合開発計画(全国, 都道府県, 地方, 特定地域)を規定 した.このような背景からまず，特定地域総合開発計画 の策定作業が先行し，第一次の全国総合開発計画は1962
表-1 目標16)，答申内容 ${ }^{15)}$

\begin{tabular}{|c|l|l|}
\hline 地域名 & \multicolumn{1}{|c|}{ 目標 } & \multicolumn{1}{|c|}{ 答申内主導目標,2副次目標 } \\
\hline 大山出雲 & 1)農業,国土保全 & 隠岐島に係る記述な \\
(隠岐島) & 2)水産業,林業 & し. \\
\hline 南九州 & 1)国土保全 & 屋久島について,資源 \\
(屋久島, & 2)水産業,林業, & は豊富だが,利用方法 \\
種子島) & 発電 & が困難. \\
\hline 対馬 & 1)水産業,(社会福祉向上) & 離島の特性上,後進性 \\
(対馬島) & 2)鉱業 & が著しい. (略) \\
\hline
\end{tabular}

表-2 特定地域計画の経過21)

\begin{tabular}{|c|c|c|c|c|}
\hline 地域名 & 提出月日 & 諮問月日 & 審議会 & 閣議決定 \\
\hline 大山出雲 & 1953.2 .23 & 1953.3 .27 & 1953.6 .29 & 1954.6 .11 \\
\hline 南九州 & 1953.3 .30 & \multirow{2}{*}{1953.6 .10} & 1953.7 .29 & \multirow{2}{*}{1954.6 .11} \\
& 1952.12 .1 & & 1954.3 .18 & \\
\hline 対馬 & 1952.12 .1 & 1952.12 .22 & 1952.1223 & - \\
\hline
\end{tabular}

(S37)年に策定された.

また当時の産業政策は, 生産力回復と傾斜生産(鉄鋼, 石炭), 企業合理化の推進により経済自立化に向けた産 業の国際競争力の向上・産業合理化が促進され, 国は産 業関連施設の整備を進め, “公共の利益”を主眼にしたも のから“企業の合理化”に重点をおく転換期にあった。

当時，経済の自立には大きく以下の $2 つ の$ 潮流があっ た. 1)国内の土地，水，地下資源等を総合的に保全，利 用，開発する「国内資源の徹底的開発」=国総法による 「特定地域総合開発計画」，2輸出入の規模を拡大し世 界市場を相手にした「産業の国際競争力の向上」＝産 業・企業合理化のための「産業関連施設の整備」.

\section{a) 国総法の特定地域指定状況}

1951(S26)年，特定地域総合開発計画の策定にあたり 19 の特定地域が指定された。 このうち離島が含まれる地域 は, 次の3地域でいずれも大型離島のみであった，1)大 山出雲地域(一部に島根県隠岐島)，2)南九州地域(一部に 鹿児島県屋久島, 種子島), 3)対馬地域(長崎県対馬島). 対馬島は1島での指定であったが，他2地域は本土地域と 合わせた地域指定であった.

\section{b) 国総法の特定地域の指定基準}

特定地域の指定基準における基本方針15は，「国民経 済発展の方向に照応し経済自立目標達成に寄与する資源 開発，産業振興並びに国土保全，災害防除等に関し(中 略), その実施により著しく効果の増大を期待し得る地 域を指定するもの」で，その主導目標は，1)資源開発地 域，2)国土保全・災害防除区域，3都市および周辺整備 地域，4)その他の地域 の4種類. 離島に係る3地域におけ る主導目標19や審議会の答申内容等 ${ }^{15}$ 離島の記述に着 目して表-1にまとめた.

対馬島・屋久島についての記述は認められるが，「離 島であるが故にその著しい効果, 利用方法が困難」とさ 


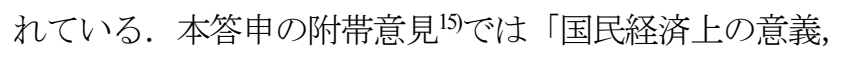
影響や資金効率等の規模加ら，緩急順序を考え，総合効 果の最も上がるような地域及び事業を優先的に取り上げ て, 開発を進めてゆくのが望ましい」とされ，離島では その著しい効果や利用方法が困難なため, 経済効果の波 及と効率性から，地域指定されても離島開発が後手にな るのは明白であった。

\section{c） 国総法の特定地域総合開発計画の策定}

特定地域の指定により関係都県はその計画書を作成し 提出しなければならないが，その主要開発目標，根幹事 業，関連事業等は総理大臣が指定すべきもので1952年4 月に通知された. その後, 離島関係地域の計画書の提出 や諮問, 審議会, 閣議決定は表-2の通りである.

特定地域総合開発計画の提出および諮問，審議は，対 馬地域が19地域の中でも4番目に早く提出・諮問・審議 されたが, 最終的には離振法適用を理由に, 唯一閣議決 定を受けていない。しかし，後述するが関係機関が離振 法立法を展開するのは1953年1月，成立は同年7月，対馬 島の離振対策実施地域指定は1953年10月。加えて, 他3 島(隠岐島, 屋久島, 種子島)の離振法地域指定も同日.

これら日付と表-2の日付からもわかる通り, 前述の特 定地域指定に対寸る答申の附带意見からも，対馬開発に 積極的ではなかったことがわかる.

\section{d) まとめ}

国は，戦後日本の経済的自立のために，国内資源の徹 底した開発を目途に国総法の特定地域総合開発計画を進 めるが，国民経済や産業振興への影響や資金効率等の観 点から，大規模な根幹事業(例えば多目的ダム建設等)に より特定地域の住民の利益よりも，より広域で全国的な 利益, また総合効果の期待できる地域を優先的に推進す る方針であった，そのため離島は，離島であるが故の立 地条件から, その効果や利用方法が困難とされ, 開発の 優先順位はきわめて低かった。「特定地域指定の諮問に 対する答申」 ${ }^{15}$ において国土総合開発審議会は「離島の 特性上後進性が著しく, (中略)住民の生活水準は更に低 く(中略)島内の資本の蓄積は乏しく, 人口の増加を制約 せざるを得ないような状態」とし，他地域とは異なる性 格，特殊事情を考慮せざるべきとして何らかの対処は必 要だとしながらも, 国の情勢からその対応順位は低かっ たのである.

\section{(2) 都県}

\section{a) 島根県}

1950-51(S25-26)年に渡って島根県では干ばつ被害22)があ り，1951(S26)年隠岐島の視察と調査に当時新設の島根県 企画室が出向いている. 離島では一般的に平地に乏しく, 傾斜耕地が多くなる23). 当時, 実際に調査に出向いた竹 下氏は，鈴木ののインタビューにて「一団地の面積が狭
く, 農地の災害復旧制度の採択基準に満たないために採 択されない，昔の法律から通達まで読んでも災害復旧に 関しては国庫補助率と採択基準の二つのために零細な農 業者には恩典はないことがわかった(筆者にて要約)」と 述懷している，当時の県は災害復旧制度の適用を考えた が，農地は一団の土地面積が狭いため採択基準を満たさ ず，また国庫補助率 $1 / 2 て ゙ は$ 残り $1 / 2$ を役場が持つ能力が ない等制度適用が困難で，離島開発法というべき法制定 の必要性を痛感(24),25)している.

企画室は各省に離島開発の方法を相談し, 関係省庁 (経審庁，建設省，農林省等)の来県に際し無理に隠岐島

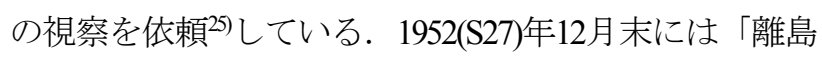
開発法(仮称)要綱」案を作成, 同時期に長崎県知事から 島根県知事宛に親書が届き(30日)，立法に向けた事態は 一気に動き出している.

\section{b) 長崎県}

日本一の離島数の長崎県は県面積の約 $1 / 3$ 離島で, 県民の約 $1 / 4$ 当時居住していた. 対馬島は朝鮮半島か らわずか約 $50 \mathrm{~km}$ で, 戦時中は防衛上の要塞と化し自由 な振興が許される状況になく, 戦後も隣国による対馬の 領有宣言や朝鮮戦争勃発等対馬島を取り巻く世情が不安 定な中，1951(S26)年国の特定地域に対馬島が指定された。 一方, その他多数の離島開発を県単独事業での実施は甚 だ困難で, 離島開発を旨とする特別法の必要性を実感 している. 1952(S27)年12月特定地域の審議(表-2)で上京 した副知事と企画室は離島開発について経審庁に相談し 島根県の動向を知り, 帰県後, 大型離島を所有する鹿児 島県, 東京都, 島根県, 新潟県の各知事に対し長崎県知 事の親書を送って，立法に向けて一気に動き出している.

\section{c）その他都県}

東京都では伊豆諸島の開発事業を立法措置で進める構 想があったが, その後都道府県総合開発の一環として

「伊豆島しょ」が作成されたことを受け，「伊豆諸島地 域総合開発事業計画書」を策定し建設省に提出している. しかし，その内容が建設省のみの事業ではなかったため, 建設省も都も模索引していた。

全く別の動きで佐賀県では，GHQ中尉が県内8島を視 察, 島民の生活水準の低さの改善を県知事に進言し, 1950(S25)年離島振興委員会が発足している．当時全国一 の赤字県が県単独事業として土地改良事業を進めている が，立法の動きには至っていない1,3.3.

\section{d) まとめ}

長崎県知事の親書をきっかけに, 島根県と長崎県を中 心とした立法が加速度的に展開していった1,21,3). その親 書送付のきっかけは，1952(S27)年12月国総法の特定地域 総合開発計画の審議における上京で, 前節表-2の日付と も符合する. 関係都県は国総法の特定地域の指定で離島 開発に期待したが，前述のとおり，特定地域総合開発計 
画による離島開発の優先順位が極めて低いことが判明し， 長崎県は大型離島の関係都県に親書を送付, 別の対策検 討の協力体制を提案したと考えられる.

長崎県知事から親書を受け取った(1952.12.30)島根県は, 翌年1月9-10日に長崎県へ出向き, 法案の検討, 5都県知 事会合の段取り，法制定の運動展開等を協議し，両県は ともに上京, 12 日農林省, 経審庁に国の協力を強く要請 し，14日東京・新潟・島根・長崎・鹿児島の5県知事は 「離島振興法(仮称)制定に関する趣意書」を作成した。

\section{(3) 学者グループ・ 九学会連合 1 ,3,2,20,27,28)}

九学会連合(日本人類学会 $\cdot$ 日本言語学会 $\cdot$ 日本考古 学会・ 日本宗教学会 $\cdot$ 日本民族学協会・ 日本民俗学会 . 日本社会学会・日本心理学会・日本地理学会)は, 195051(S25-26)年に延120人による戦後初の大規模な地域調査

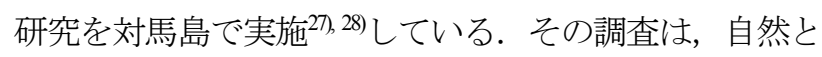
人文の広い範囲に渡って各界の有名な研究者により緻密 な調査が実施され，同時に漁業制度の抜本的な改革を検 討していた水産庁の調査も兼ねられ，これら調査を通じ て離島の「後進性」が見出され，立法運動への強力な支 援に繋がった。

本調査に深く関わった島嶼社会研究会は1950(S25)年6 月に設立し, 特筆すべき人物として宮本常一, 山階(浅 野)芳正が挙げられる. 趣意書を提出した5都県は，本研 究会の有志と会合を開き, 法案の内容等について意見を 求めている1,3). その要旨は次の通り。1)「離島」は学問 上不明確であり，離島の定義を法令に規定することは望 ましくない，2)対象地域は弾力的に拡大寸心゙き，3)将来 は内海の島嶼にも適用すべき，4)全国の離島民の組織が 必要. 離振法では，実際に離島の定義はなされず，対象 となる離島も段階的に拡大, この後すべてに対応した. これは, 離振法成立直前の「全国離島民代表者踿起大
会」の開催，離島民の組織「全国離島振興協議会」が6 都県(熊本県参加)179町村で結成され，その事務局を島嶼 社会研究会の学者が担ったことが影響していると考える.

\section{(4) まとめ}

関係都県の実質的問題は，各地域の実状によって違い はあるものの，島民の“民生の安定と生活環境の改善”に 集約される．学界グループが関係都県を支援したのも， 地域調查を通じて離島の隔絶性と条件不利性からくる後 進性の改善の必要性を見出したからである.

ここに当時の国の地域振興方針“広範な利益, 大規模 な経済効果”と, 関係都県の基本方針“民生の安定と生活 環境の改善”とに大きなギャップがあったことがわかっ た(図-1). そのため, 国総法の特定地域総合開発計画等 ではなく, 離島に特化した特別法の立法が必要であった。

\section{4. 後進性に着目した離島の状況}

離振法は，離島における後進性の除去と民生の安定を 第一義的目標として成立し, この目標達成により法律が 不要となるため 10 年の時限立法であった. そこで, 当時 の後進性の状況を把握するため, 離島の後進性について 記載された文献を調查し, 当時の離島課題のひとつであ る人口過剩状況から「自給率」と, 経済状況を把握寸る ための「産業構造とその所得」を調査する.

\section{(1) 文献調查}

離島の後進性について記述された3つの文献を整理し た結果，離島の後進性は，離振法成立当初から“自明の 理”とされ，その状況は不明確で，明文化されていない ことがわかった. 振興以前の天草島の調查により，1)島

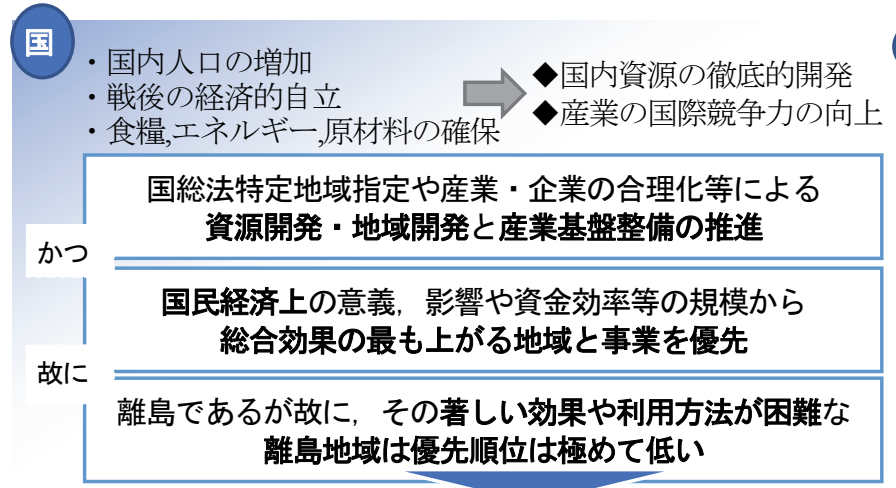

\section{都県}

【島根県】

・隠岐島での干ばつ被害におけ る災害復旧制度の適用不可。

【長崎県】

対馬島以外の多くの離島は国 総法特定地域総合開発の対象 外.

既存制度での採択基準適用 困難と財政力不足

\section{学界}

- 九学会連合, 島 嶼社会研究会に よる対馬島の大 規模調查.

社会構造上. 地形的条件不 利性からの 後進性の指摘

広範な利益，大規模な経済効果 
民生活水準の低位さ，2)資本の欠如，3)公共施設の薄さ， という状況は示されているが，どの文献も何をもって後 進性とみなすかを明示していない. 詳細を次に示す.

\section{・離島に関する調査報告(1955) ${ }^{29)}$}

農林省がまとめた本書は, 当時特殊地域立法が相次ぐ 中, 日本農業研究所の西村によって天草島の離島振興の 調查項目51項目をもとに後進性が何かを追究している.

それによると離島の後進性は，「1)島民生活水準の低 位なること，2)資本の欠如，3)公共施設の薄いこと」と しているが,「離島の地形的特徵(本土との隔絶性, 周 囲が海であること，一定面積以下であること)を基礎に 生じたものと, 本土の僻地でも生じるものがあるため, 離島であるが故に直ちに補助方式を変更すべきとは断定 できない」と結論づけている.

\section{・離島の現状とこれからの離島振興(1972) ${ }^{30}$}

離振法による離島振興が20年経過した際，全国離島振 興協議会は本稿の一節に「3. 離島の現状一その後進 性」として後進性の指標例13項目を表記している.

これら指標は, 離振法の事業による振興状況の進捗を 数值的にわかりやすく測るための指標である. 後進性を 何をもって測るかは人によって解釈が違うとしている.

\section{・離島振興対策の現状と課題(1992) ${ }^{31)}$}

本稿は, 法制定当時から学界支援者の中心人物の一人 である山階芳正氏の論考で，法制定から約40年後に執筆 されている. そこには，執筆当時の離振法の問題点の一 つとして，「“後進性”が自明の理とされて何の説明もな く，具体的に何をもって後進性とみな寸かは不明であ る」とし，本土と離島との経済的格差が解消したとして も, 社会的・文化的格差が存在する限り, 離島住民は満 足しないであろう」と指摘している.

\section{（2）人口過剰と自給率}

当時の多くの離島は, 現在の人口減少問題とは違い, 人口過剩が問題15, 27, 28), 29)であった．人口過剩は，一定地 域の経済的人口収容力に対して人口が多すぎる状態をい うが，ここでは人口を扶養するに足る食糧供給量を量る 指標として「自給率」に着目寸る.

人口過剩は，食糧の自給不足問題を引き起こす，その ため，かっては島によって人口制限をすることでからう じて食糧自給を保っていたが，明治以降に人口制限が薄 れて人口過剩となり, 食糧の自給が追いついていない.

そこで，農林省「離島の現況22」」の34島のデータ(例：

写真-1)から, 当時(1950(S25)年頃)の県別自給率と全国の 自給率33)を，主要品目別に表-3にまとめる，なお，離島 のデータは，自給率 $(\%)=$ 生産量／地区内消費量で筆者に て算出した.

その結果, 離島の米の自給率が低く, 島外からの移入 に依存していることがわかる. 麦は地区内消費量が少な い分, 島内の生産量で一定量賄えていることがわかる.

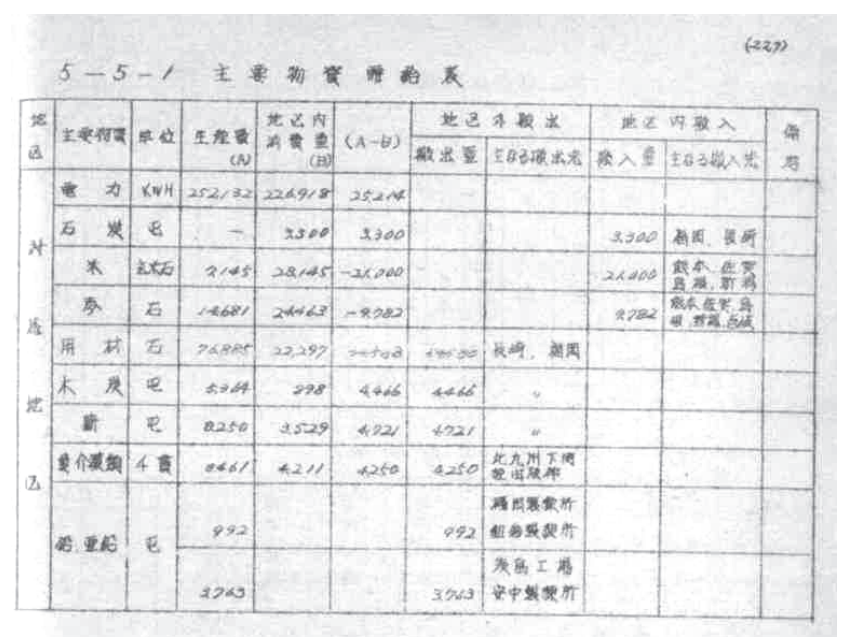

写真-1 農林省「離島の現況 $32 」$ デー夕例 : 対馬島 (原本 : 国立国会図書館内デジタル化資料より)

表-3 1950年頃の主要品目別自給率(県別)

\begin{tabular}{|c|c|c|c|c|c|c|c|c|c|}
\hline 都県 & \multicolumn{2}{|l|}{ 米 } & [有効数:32] & \multicolumn{2}{|c|}{ 麦 } & [有効数:31] & \multicolumn{2}{|c|}{ 魚介藻類 } & [有効数: $: 30$ ] \\
\hline 34島数 & 生産量 & 地区内消費量 & 自給率 & 生産量 & 地区内消費量 & 自給率 & 生産量 & 地区内消費量 & 自給率 \\
\hline & A (石) & B (石) & A/B (\%) & A (石) & B (石) & A/B (\%) & A (貫) & B（貫） & A/B (\%) \\
\hline 東京都 & 1,021 & 18,376 & 6 & 5,227 & - & - & $2,406,000$ & 468,264 & 514 \\
\hline 新潟県 & 270,844 & 187,316 & 145 & 21,541 & 21,390 & 101 & $3,321,389$ & 205,558 & 1616 \\
\hline 三重県 & 463 & 6,090 & 8 & 649 & 2,726 & 24 & 976,635 & 8,455 & 11551 \\
\hline 愛媛県 & 0 & 1,285 & 0 & 1,413 & 1,632 & 87 & $1,204,000$ & 74,000 & 1627 \\
\hline 山口県 & 2,451 & 2,627 & 93 & 4,751 & 3,581 & 133 & - & - & - \\
\hline 長崎県 & 119,486 & 291,870 & 41 & 135,031 & 145,540 & 93 & $160,639,000$ & $107,437,125$ & 150 \\
\hline 佐賀県 & 207 & 2,109 & 10 & 1,400 & 1,086 & 129 & $1,448,000$ & 100,100 & 1447 \\
\hline 熊本県 & 97,000 & 220,000 & 44 & 86,000 & 94,100 & 91 & $11,461,000$ & $4,584,400$ & 250 \\
\hline 鹿児島県 & 46,176 & 75,113 & 61 & 27,894 & 46,449 & 60 & $3,385,000$ & $1,397,000$ & 242 \\
\hline 合計 & 537,648 & 804,786 & 67 & 278,679 & 316,504 & 88 & $184,841,024$ & $114,274,902$ & 162 \\
\hline 全国 & & & 89 & & 43(小麦 & ) · 53(大麦) & & & 100 \\
\hline
\end{tabular}


表-4 1960年における産業別人口割合(\%)と一人当り所得額(千円)

\begin{tabular}{|c|c|c|c|c|c|c|c|c|c|c|c|c|c|c|c|c|}
\hline & & \multicolumn{4}{|c|}{ 第一次産業 } & \multicolumn{4}{|c|}{ 第二次産業 } & \multicolumn{6}{|c|}{ 第三次産業 } & \\
\hline \multirow{2}{*}{$\begin{array}{c}\text { 人口割合 } \\
(\%)\end{array}$} & 離島 & \multicolumn{4}{|c|}{64} & \multicolumn{4}{|c|}{13} & \multicolumn{6}{|c|}{23} & \\
\hline & 全国 & \multicolumn{4}{|c|}{33} & \multicolumn{4}{|c|}{30} & \multicolumn{6}{|c|}{38} & \\
\hline 所得額 & 離島 & \multicolumn{4}{|c|}{84} & \multicolumn{4}{|c|}{238} & \multicolumn{6}{|c|}{230} & \\
\hline \multirow[t]{2}{*}{ （千円） } & 全国 & \multicolumn{4}{|c|}{135} & \multicolumn{4}{|c|}{379} & \multicolumn{6}{|c|}{392} & \\
\hline & 全国比 & \multicolumn{4}{|c|}{$62 \%$} & \multirow{2}{*}{\multicolumn{4}{|c|}{$\begin{array}{l}\text { 63\% } \\
\text { 県別内訳 (千円) }\end{array}$}} & \multirow{2}{*}{\multicolumn{6}{|c|}{$59 \%$}} & \\
\hline \multicolumn{7}{|c|}{ 県別内訳 (千円) } & & & & & & & & & & \\
\hline \multirow[b]{2}{*}{ 都県 } & \multirow{2}{*}{$\begin{array}{c}\overrightarrow{テ ゙ ー タ ~} \\
\text { 島数 }\end{array}$} & \multicolumn{4}{|c|}{ 第一次産業 } & & 第二: & 産業 & & & & 第三次 & 欠産業 & & & \\
\hline & & 総計 & 農業 & 林業 & 水産業 & 総計 & 鉱業 & 建設業 & 製造業 & 総計 & $\begin{array}{l}\text { 卸売 } \\
\text { 小売業 }\end{array}$ & $\begin{array}{c}\text { 金融· } \\
\text { 不動産業 } \\
\end{array}$ & $\begin{array}{l}\text { 運輸通信業 } \\
\text { 公益事業 } \\
\end{array}$ & サービス業 & 公務 & 総計 \\
\hline 宮城県 & 10 & 185 & 37 & 6,685 & 230 & 44 & - & 84 & 14 & 187 & 163 & - & 156 & 186 & 319 & 178 \\
\hline 山形県 & 1 & 53 & 33 & - & 85 & 100 & - & 99 & 120 & 130 & 174 & - & 184 & 106 & 130 & 63 \\
\hline 新潟県 & 2 & 104 & 80 & 784 & 230 & 160 & 149 & 142 & 180 & 256 & 227 & 631 & 421 & 190 & 290 & 148 \\
\hline 東京都 & 10 & 127 & 80 & 230 & 216 & 239 & 336 & 248 & 216 & 294 & 256 & 317 & 232 & 256 & 359 & 193 \\
\hline 静岡県 & 1 & 81 & 44 & - & 156 & - & - & - & - & 143 & 83 & - & 200 & 39 & 580 & 101 \\
\hline 愛知県 & 3 & 94 & 29 & - & 109 & 122 & - & 136 & 119 & 135 & 137 & 140 & 127 & 136 & 135 & 101 \\
\hline 三重県 & 6 & 71 & 29 & 58 & 82 & 231 & 216 & 133 & 262 & 236 & 276 & 294 & 154 & 244 & 339 & 133 \\
\hline 石川県 & 2 & 73 & 52 & 1,187 & 154 & 112 & 506 & 95 & 84 & 88 & 56 & - & 99 & 93 & 117 & 75 \\
\hline 和歌山県 & 1 & 141 & 82 & 362 & 202 & 161 & - & 160 & 165 & 228 & 227 & 853 & 243 & 186 & 307 & 165 \\
\hline 兵庫県 & 5 & 160 & 50 & - & 179 & 275 & 210 & 277 & 554 & 173 & 255 & 222 & 151 & 163 & 186 & 184 \\
\hline 島根県 & 5 & 122 & 50 & 331 & 242 & 170 & 260 & 154 & 187 & 231 & - & - & - & - & - & 161 \\
\hline 岡山県 & 17 & 55 & 50 & 31 & 65 & 205 & 206 & 111 & 229 & 129 & 143 & 170 & 187 & 169 & 174 & 113 \\
\hline 広島県 & 29 & 108 & 107 & 108 & 103 & 220 & 345 & 166 & 250 & 240 & 143 & 1,001 & 283 & 249 & 288 & 141 \\
\hline 山口県 & 29 & 72 & 46 & 139 & 121 & 196 & 150 & 188 & 247 & 217 & 98 & 286 & 272 & 212 & 257 & 104 \\
\hline 香川県 & 22 & 81 & 54 & 306 & 117 & 145 & 168 & 115 & 134 & 176 & 134 & 327 & 257 & 135 & 168 & 106 \\
\hline 愛媛県 & 61 & 106 & 100 & 592 & 117 & 183 & 223 & 110 & 206 & 145 & 95 & 305 & 187 & 116 & 211 & 125 \\
\hline 徳島県 & 2 & 146 & 88 & - & 147 & - & - & - & - & 157 & 217 & - & 77 & 169 & 141 & 145 \\
\hline 高知県 & 3 & 40 & 13 & 163 & 55 & 140 & - & 83 & 311 & 255 & - & - & - & - & - & 57 \\
\hline 福岡県 & 9 & 87 & 51 & 180 & 97 & 218 & 360 & 197 & 200 & 200 & 105 & - & 216 & 229 & 246 & 106 \\
\hline 佐賀県 & 8 & 74 & 37 & - & 116 & 164 & - & 160 & 167 & 232 & 110 & - & 180 & 101 & 311 & 85 \\
\hline 長崎県 & 83 & 82 & 47 & 163 & 166 & 270 & 396 & 129 & 129 & 235 & 211 & 660 & 240 & 208 & 299 & 151 \\
\hline 大分県 & 7 & 83 & 36 & 1,227 & 115 & 148 & 105 & 136 & 174 & 190 & 224 & 100 & 180 & 157 & 248 & 103 \\
\hline 熊本県 & 29 & 92 & 60 & 912 & 107 & 182 & 224 & 178 & 139 & 235 & 165 & 1,172 & 203 & 274 & 288 & 142 \\
\hline 宮崎県 & 2 & 142 & 226 & 648 & 137 & 142 & - & 75 & 150 & 122 & 95 & - & 81 & 138 & 255 & 139 \\
\hline 鹿児島県 & 25 & 80 & 68 & 276 & 138 & 251 & 508 & 283 & 176 & 217 & - & - & - & - & - & 117 \\
\hline
\end{tabular}

魚介藻類は，生産量も多く地区内消費量も少ないことか ら自給率100\%を超えている.

離島別に米の自給率をみると，自給率が $100 \%$ を超え

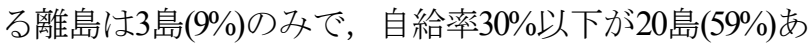
り，そのうち6島(18\%)が自給率0\%であった。

米の自給率が低い原因は，1)地形的地質的にも耕地が 少ないこと，2)水量・水質の両面の問題から常日頃から 水不足で水田には恵まれないこと，3)農業技術が発達し なかったこと，にある23, 27, 28, 29, 34)。これは，海による隔 絶と特徵的な地形地質条件によるものである.

また食糧移入は，定期船等の船次第で，天候や港湾設 備の未発達により接岸できない場合は食糧移入もできな い. これは海による隔絶が引き起こす後進状況と考える.

\section{(3) 産業別人口とその所得額}

海に囲まれている立地条件からも当時の離島では，漁 業が一番盛んと考えるが，就業人口からすると農業が第 一位で, 漁業を副業的に営む兼業農家，半農半漁が多い． これは，1)藩政時代からの社会構造上，本百姓が漁業権 を持っていたこと，2)隔絶された離島であるが故に農業 技術・漁業技術が発展しなかったこと，3)農業(米)が自 給的な面を持つ一方, 漁業(魚)は農作物との交換が必要 になること, が挙げられる23,27,28),299,34.

この当時(1960(S35)年)の産業別人口割合とその一人当
り所得額 $[1][2]$ [3] [4]を表-4にまとめた。なお，離島別所得額 は，372島の離島別所得額を経済企画庁総合開発局がと りまとめたもので，それを筆者にて県別にまとめた．本 資料は国立国会図書館に所蔵されているが，撮影，複写， 別室からの持ち出し禁止のため, 筆者にて別室で書き写 した．そのため，原本写真の掲載は不可能である.

離島は産業基盤が脆弱で第二，三次産業が未発達のた め, 第一次産業人口の比率が高く, また一人当りの所得 額は，全国の約7割弱である. 離島民の就業者の半数以 上が従事している第一次産業の一人当りの所得額は，第 二，三次産業の約4割程にしか過ぎない。

これは，島民自身における事業の発展や起業等の資本 不足であると同時に，行財政力も乏しいことがわかる.

\section{(4) まとめ}

制定当時の離島の状況は, 人口過剩により食糧の自給 不足で，食糧移入と島外への出稼ぎに頼っており，また 就業者の半数以上が第一次産業従事者で，その一人当り の所得額は低く，離島民自身による産業振興等への資本 力不足や，行財政力の乏しさを生み出した.

あわせて，封建的な社会構造が維持されたことや農 業・漁業技術の未発達, 電気・水道の未普及, インフラ の未発達等は, 海による隔絶と特徽的な地形地質条件等 に起因するものであると考える. 


\section{5. おわりに}

以上, 本研究では離振法の成立背景, 後進性に着目し て当時の離島の経済社会状況を明らかにした，得られた 知見は以下の通りである.

＜離島振興法の成立背景 $>$

- 国総法特定地域総合開発計画は国民経済や産業振興へ の影響や資金効率等の観点から，地域住民の利益より も，より広域で全国的な利益，また総合効果の期待で きる地域を優先的に推進する方針であったため，離島 開発の優先順位はきわめて低かった.

- 離島の地形的特徵と関係都県・市町村の行財政力の乏 しさは, 既存制度での採択基準適用の困難さと補助率 の問題，財政力不足等の問題を発生させ，島民の“民 生の安定と生活環境の改善”のために離島に特化した 立法の必要性があった。

- 国の地域振興方針“広範な利益, 大規模な経済効果”之, 離島関係都県の基本方針“民生の安定と生活環境の改 善”とに離島振興のスタンスの違いがあった。

・離振法成立は，実質的な問題を抱えていた島根県と長 崎県の危機感と強い推進力に加え, 学界からの強力な バックアップが後押しした。

＜後進性に着目した当時の経済社会状況＞

・食糧の自給不足は，人口過剩と生産力の低さが原因と 考えられ，その状況は，食糧移入と島外への出稼ぎを 生多出していた.

・産業基盤が脆弱で第二, 三次産業が未発展のため, 就 業者の半数以上が第一次産業である産業構造は離島の 特徵で, その一人当りの所得額が低いことは, 離島民 自身による産業振興等に対寸る資本力不足, 行財政力 の乏しさから後進の状況を生み出した。

- 産業振興の障壁は, 離島民の資本力不足と電力・水不 足, 産業基盤(島内道路, 港湾等)の未発達, 隔絶状況 による技術移入の困難さにある.

当時の離島の社会経済状況は, 食糧の自給や確保の困 難さのみならず，第二，三次産業の脆弱さによりそれら 産業への社会的人口収容力もなく, 第一次産業で収容す る状況にあった。 しかし第一次産業は, 農地不足や漁獲 量超過等から既に飽和状態であった.

そのため, 離島関係都県や学界は“民生の安定と生活 環境の改善”を最優先に考えた，島民の生活環境を整え るために「離島に水と光を」を合い言葉に電気と水道普 及が優先され，同時に食糧や産業資材移入・移出のため の港湾整備, 生産物運搬や産業資材運搬のための島内道 路整備等が進められた。

これらハード整備の推進には社会的人口収容の役割も あった. また産業基盤整備が推し進められた背景には国 の企業合理化による産業立地政策の影響があると考える.
この60数年の離島振興により, 後進性の用語も削除さ れ，一定水準の生活環境亡産業基盤が整えられた. しか し, 当時より人口は半減し, 若者の島外流出は止まらな い.

1996年に国連海洋法条約を批准し，海域をめぐる政策 課題が顕在化するに当り，にわかに離島の位置づけが見 直され始め，領海及び排他的経済水域等の基点となる離 島に国家的役割が付された。 また，近年の世界各地にお ける島を巡る紛争からも, 離島に日本国民が居住し経済 的生活を維持することが大きな意味を持つようになった。

このように離島の位置づけが, 後手とされた後進地域 から, 国家的役割を担うフロンティアとしての重要地域 に変化している転換期にあることがわかる.

しかし実際には, 離島の「振興」はこれまで通り離振 法で市町村からのボトムアップ方式により推進し，「保 全・管理」については海洋基本法や有人国境離島法で対 応する仕分けになっている35.

この転換期にある今，国家的・国土計画的・海洋政策 的見地から離島全体を一体的に俯瞰し，「保全・管理・ 振興」に関して長期的な視点で総合的な離島政策を検討 する必要があると考える.

その一方で，当時人口過剩と呼ばれた状況はなくなり， 消滅の危機にある集落も多数ある. 定住や経済的生活を 維持するためには，そこに住む住民が向き合っている課 題や生活状況, 離島毎に応じた産業振興等への対応が重 要となるため, 地域からボトムアップ方式によるミクロ の視点でも柔軟に対応できる2段階構造で検討寸る必要 があると考える.

今後, 離振法の事後評価や有人国境離島法との施策比 較, 両法の柱に共通している「無人島化」の原因追究に より, 離島政策の定住促進や離島の持続可能性を探って いきたいと考えている.

謝辞 : 本研究において, 谷下雅義中央大学教授には幾度 も多大なご助言を頂いた。 また，公益財団法人日本離島 センターの小澤卓氏にも貴重なご助言を頂いた．ここに 記して感謝申し上げます。

\section{補注}

[1] 1960 年離島の人口割合は, 全国離島振興協議会 : 離 島振興三十年史一上巻・離島振興のあゆみ一, pp. 252 , 1989.により。

[2] 1960 年全国の人口割合は, 全国の総理府統計局 : 国 勢調查, 1960.により。(東洋経済新報社 : 昭和国勢総 覧第一巻, pp.28, 1991.)

[3] 1960 年離島の一人当りの所得額は, 農林省: 離島関 係資料集計結果(島別)S38 47 離島振興計画指標産業 別就業者 1 人当り所得額(S35, S47), 1965.より.

[4] 1960 年全国の一人当りの所得額は, 国民生活研究 所 : 昭和 45 年版国民生活統計年報, 1970.の第 52 表 
産業別の国民純生産の推移より筆者で作成.

\section{参考文献}

1) 全国離島振興協議会：離島一その現況と対策一, pp.30-35, 1966.

2) (財)日本離島センター：離島振興 20 年の歩み, pp.5-8, 1974.

3) 全国離島振興協議会 : 離島振興三十年史一上巻 - 離 島振興のあゆみ一, pp.3-31, 1989.

4) 鈴木勇次 : 宮本常一氏のもう一つの離島振興観一一 通の手紙に託寸離島の公平性一，長崎ウエスレヤン 大学現代社会学部紀要, Vol.3, No.1, pp.1-8, 2005.

5) 鈴木勇次 : 離島振興法の原点とその目標一離島振興 対策実施地域の指定一, 長崎ウエスレヤン大学現代 社会学部紀要, Vol.4, No.1, pp.61-68, 2006.

6) 鈴木勇次 : 離島振興法の原点とその目標一竹下虎之 助元広島県知事に聞く一, 長崎ウエスレヤン大学社 会福祉学部紀要, Vol.4, No.1, pp.133-140, 2006.

7) 鈴木勇次：離島振興法に関わる個人力ー山階芳正の 活躍と貢献一, 長崎ウエスレヤン大学現代社会学部 紀要, Vol.10, No.1, pp.9-22, 2012.

8) 小澤卓 : 離島振興法の変遷と離島振興の経済分析一 制度・財政・産業からの接近一, 中央大学博士課程 学位論文(経済学), 2017.

9) 根岸裕孝：戦後日本の産業立地政策一開発思想の変 遷と政策決定のメカニズム，一財）九州大学出版会， 2018.

10) Chalmers Johnson : 通産省と日本の奇跡一産業政策の 発展 1925-1975, 勁草書房, 2018.

11) 佐藤䇥：日本の地域開発，未来社，1965.

12) 経済企画庁：経済企画庁二十年小史, pp.61-66, 1966.

13) 経済企画庁: 経済企画庁総合開発行政の歩み, pp.4649, pp.162-164, 1975.

14) 大来佐武郎：全国総合開発計画の背景と課題, 日本 地域学会年報, 1962 巻, 1 号, pp.29-39, 1962.

15) 経済企画庁開発部：総合開発参考資料増補改訂版, 1957.

16）建設省管理局企画課 監修: 国土総合開発特定地域の 梨，建設協会，1951.
17) 木村三郎(管理局企画課技官)：総合開発特定地域の現 況，建設月報，11月号，pp.1-6，1951.

18）(財)国土計画協会 : 特定地域の歩みとその問題点, 国 土, Vol.8, No.3, pp.10-36, 1958.

19）(財)国土計画協会 : 国土情報, 国土, Vol.1, No.6, pp.24-26, 1951.

20）(財)国土計画協会 : 国土情報, 国土, Vol.11, No.2, pp.43-49, 1952.

21) 有沢広已, 稲葉秀三 編 : 資料 - 戦後二十年史 第 2 , pp.320-321, 日本評論社, 1966.

22) 松江地方気象台・浜田測候所：島根の気象百年 - 創 立百年史, 1993 .

23) 藤岡謙二郎, 浮田典良 : 離島診断, 地人書房, 1975 .

24）全国離島振興協議会 : 季刊「しま」，36 号, pp.24-25, 1963.

25）全国離島振興協議会 : 季刊「しま」，36 号, pp.22-24, 1963.

26) 佐野眞一 : 旅する巨人 - 宮本常一と渋沢敬三, 1996.

27) 九学会連合：漁民と対馬, 九学会年報(人類科学)第四 集, 1952.

28）九学会連合・対馬共同調査委員会 : 対馬の自然と文 化, 古今書院, 1954.

29）農林省：離島に関する調查報告, 1955 .

30）(財)日本離島センター：季刊「しま」，71 号, pp.3163, 1972.

31) 山階芳正：防衛大学校紀要「山階教授退官記念号」, 第 64 号, pp.1-41， 1992.

32) 農林省: 離島の現況第 1 , 第 3 その 2 , 第 4 その 3 , 第 6, 1954-1955.

33) 農林省 : 改訂日本農業基礎調査, 1977. (東洋経済新 報社 : 昭和国勢総覧第三巻, pp.339, 1991.)

34）小松正之, 有薗眞琴: 実例でわかる漁業法と漁業権 の課題, 成山堂書店, 2017.

35) 久保田恵都子 : 有人国境離島法の成立背景, 土木史 研究講演集, Vol.39, pp.195-201， 2019.

(Received February 22, 2019)

(Accepted August 26, 2019)

\section{BACKGROUND OF REMOTE ISLANDS DEVELOPMENT ACT ESTABLISHMENT AND ISSUES OF REMOTE ISLANDS DEVELOPMENT PROJECTS FROM THE VIEWPOINT OF BACKWARDNESS}

\section{Etsuko KUBOTA}

Promotion of remote island regions in Japan has began with the Remote Islands Development Act established in 1953 (S28). In this paper, in order to contribute to the discussion of the remote islands development issues, the legislative background of the Remote Islands Development Act was sorted out from the necessity of legislative measures and the situation of remote islands at the time. As a result, at the time of enacting the law, 1) there was a difference in stance in the policy of regional development of the country and remote islands related prefectures, thereby 2) the priority of remote islands development was extremely low, and 3) as more than half of the workers were primary industries, their per capita income was low and capital strength and administrative power was poor. 